\title{
The Archaeology of Collapse in Azerbaijan and Eastern Anatolia at During the Iron Age
}

\author{
Mohammad Mirzaei ${ }^{1, ~ *, ~ R e z a ~ A t a e i ~}{ }^{2}$, Nasrin Alizadeh ${ }^{3}$, Peyman Rahmani ${ }^{4}$ \\ ${ }^{1}$ Department of Archaeology, University of Sistan and Baluchestan, Zahedan, Iran \\ ${ }^{2}$ Department of Archaeology, University of Tarbiat Modarres, Tehran, Iran \\ ${ }^{3}$ Department of Art, Islamic Azad University of Ramsar, Ramsar, Iran \\ ${ }^{4}$ Department of Archaeology, University of Mohagheghe Ardebili, Ardebil, Iran
}

Email address:

Mirzaii63@yahoo.com (M. Mirzaei)

${ }^{*}$ Corresponding author

\section{To cite this article:}

Mohammad Mirzaei, Reza Ataei, Nasrin Alizadeh, Peyman Rahmani. The Archaeology of Collapse in Azerbaijan and Eastern Anatolia at During the Iron Age. International Journal of Archaeology. Vol. 4, No. 5, 2016, pp. 61-67. doi: 10.11648/j.ija.20160405.12

Received: July 22, 2016; Accepted: August 2, 2016; Published: August 12, 2016

\begin{abstract}
Knowledge, analysis and review of rise and fall of civilizations are one of the equivocal and tremendous topics with which the experts have dealt. Those factors that may influence in collapse of human communities are as follows: Human, economic, social, cultural and environmental factors. In some cases, natural disasters such as tsunami, earthquake, wide fire, and climatic changes and also on some occasions other factors including military invasion, attacks by barbarian and wild tribes, oppression of owners of power as well as civil revolts and ethnic-tribal problems may lead to civilization collapse. Iron Age covers time period (1500-500BC) in Iranian archeology when human could extract iron metal and use it from more production, the sites in Iron Age have been formed by production of grey potteries and use of iron-made tools. The present essay is intended to give answer to this effective question by means of descriptive- analytical method that at what scale the influential factors have occurred and how collapse and destruction took place in areas of Azerbaijan during Iron Age (Northwest of Iran and Eastern Anatolia). The results of this study show that the large areas such as Hasanlu, Dinkha Tepe, and Bastam and even regions of monarchical government of Urartian Empire in Eastern Turkey (Ayanis, Norshun-Tepe, Kayalıdere, Altıntepe, Yoncatepe and so on) have been demolished due to sudden accident and conflagration during this period and they have been diminished from scene of time.
\end{abstract}

Keywords: Azerbaijan, Iron Age, Collapse, Fire and Destruction

\section{Introduction}

Emerging, growth, destruction, and collapse of civilizations and cultures and extending them to all civilization is deemed as an effort has made since time of Ibn- Khaldun by some of theorists. Ibn- Khaldun as founder of this topic has called this issue civil science as synonymous with civilization and culture and called it as philosophy of history [22]. Collapse here means stopping growth of a civilization or destruction and demolition or slow trend of its growth; whether this demolition caused by humans or due to accidents and natural disasters. In collapse and fall it is discussed on communities and civilizations that have suddenly disappeared instead of exercising gradual transformation. Archeologists use term of collapse to describe communities that have been quickly simplified i.e. a model in which cities and villages are depopulated and population mass are reduced [23]. Many theories have been posited as an effort to explain collapse where it has been referred to some them in the following. The present article tries to analyze this region based on archeological data resulting from excavations on reasons of collapse and termination of inhabitance in areas at Iron Age in this region.

\section{Methodology}

One of the paramount questions that require scientific and 
even realistic strategy to give them answers is paying attention to political equations in this region and causes of collapse and fall of Northwestern areas of Iran where method of description and analysis on archeological data derived from collection of reports have been utilized in this essay for archeological excavations in these areas as well as using of other librarian sources. Inter alia, the comments and works of researchers, who have professionally studied fall and collapse of civilizations, have been also utilized to achieve favorable outcome.

\subsection{Literature of Research}

Unfortunately no independent study has been so far conducted by informative identity regarding political developments at Northwest of Iran during discussed period. Most of archeological collapse experts have distributed their attitudes in Roman Empire [26], Bronze Age in Greece [7], Indus and Maya Civilizations [5], Uruk in East Turkey [11], and Mesopotamia [30]. Position of collapse in Iron Age areas at Northwest of Iran is assumed as blind spots in history of this region where the current paper can be considered as one of the first sources of this kind.

\subsection{Theories and Approaches of Various Schools about Fall and Collapse of Civilizations}

According to attitude of Ibn Khaldun attitude, governments and nations are born similar to a human and they are led to fall and demolition after growth and flourishing and sovereignty. In fact, he has proposed a theory that can be classified in group of cyclic theories on civilization [1]. Also Toynbee has put cyclic theory of civilization as the basis for his work and he believed that any civilization has emerged and formed according to the responses given to a group of challenges. Based on attitude of Toynbee, as long as community responds to challenges it can grow and survive but if it fails to do this task, demolition and fall starts for it [27]. Some experts believe that Roman Empire collapsed due to failure in reaction to internal challenges and external enemies [23]. Civilizations start from a point and gradually reach to the peak point and then fall down and diminish or pause. After a while, they are also ruined and this movement trend is always prevalent among civilization. Luis Morgan, an American anthropologist, also believed that the communities were passed through three main phases of savagery, barbarism, and civilization [19].

General factors of fall and collapse of human communities may be classified within framework of environmental and cultural factors of systems. The environmental factors include climatic changes, reduced available resources, and eruption of volcanoes, earthquake, flood, drought, and famine. At the end of Bronze Age, drought took place in some areas at Greece, Turkey, and Middle East that led to destruction of many civilizations in these regions [29]. Also, flooding irrigation in Mesopotamia for more production has caused extreme salinization of farmlands and followed by collapse of third monarchical Ur Dynasty [23].

Cultural factors comprise of demographic changes, immigration, sudden revolts, and technological advancement followed by changes in technique of wars. Changes in wars such as innovation in warfare, use of new weapon and armors, utilization from war chariots, and appearance of infantries by some of communities have led them to start conquest, pillage, and destruction of other societies [6]. One of the main signs of invasion is to discover fixed skeletons remained unburied on site of accident after revolt [28].

Collapse of public systems in a society may be also followed by demolition of the given community. One of the features of any community is the rate of complexity of the aforesaid society, which explains how a community includes widely different rules, experts, technology, and information and what institutes administer public life and in such a center, absence of expertise, lack of centralization, weakness in political and economic and social organization as well as absence of foreign trade will lead to gradual fall of civilization [3]. Mrs. Frangipane has posited dissolution of systems about collapse of Uruk period in Middle and Upper Euphrates [11].

\subsection{Iron Age in Azerbaijan}

Azerbaijan (Fig. 1) is located in Northwestern Iran. There are main Iron Age settlements in this area. Iron Age is the last period for prehistoric communities in terms of classification and based on technology and tools. This period that covers time range (1500-500BC) in Iranian archeological terminology is a period that appeared after demolition of cultures at Bronze Age with some features such as construction of graves outside living places, construction and developing grey porcelain and potteries, extraction and utilization from iron metal, use of defensive architecture, use of war chariots, and above all emerging of great powers including Urartu, Mannea, and Assyrians and it has been divided into three periods of Iron Age I, II, and III [8]; [31]. Many areas started formation at the end of Iron Age I (1450-1200BC) and in Iron Age II (1200-800BC) this trend reached to the climax and at the end of this period (i.e. about $800 \mathrm{BC}$ ) they started destruction and desolation. The special position is assumed for Age Iron II in archeological studies on Iran. Hasanlu is placed in Sulduz Valley at peak point and flourishing era at early days of this period while it was destroyed within a sudden project at the end of this period. Range of such destruction also covers many other areas were at this date and afterwards (Iron Age III), they disappeared one after another. Many areas have been formed by distinct culture of Iron Age at this period and they have fallen down at the end of it including Hasanlu, Bastam, Agrab Tepe, Dinkha Tepe, Kordlar Tepe, Ziwiye, and even Babajan Tepe, and Tepe Nush-i Jan Tepe, and other small areas. All of these areas have reached to collapse phase with the same image. 


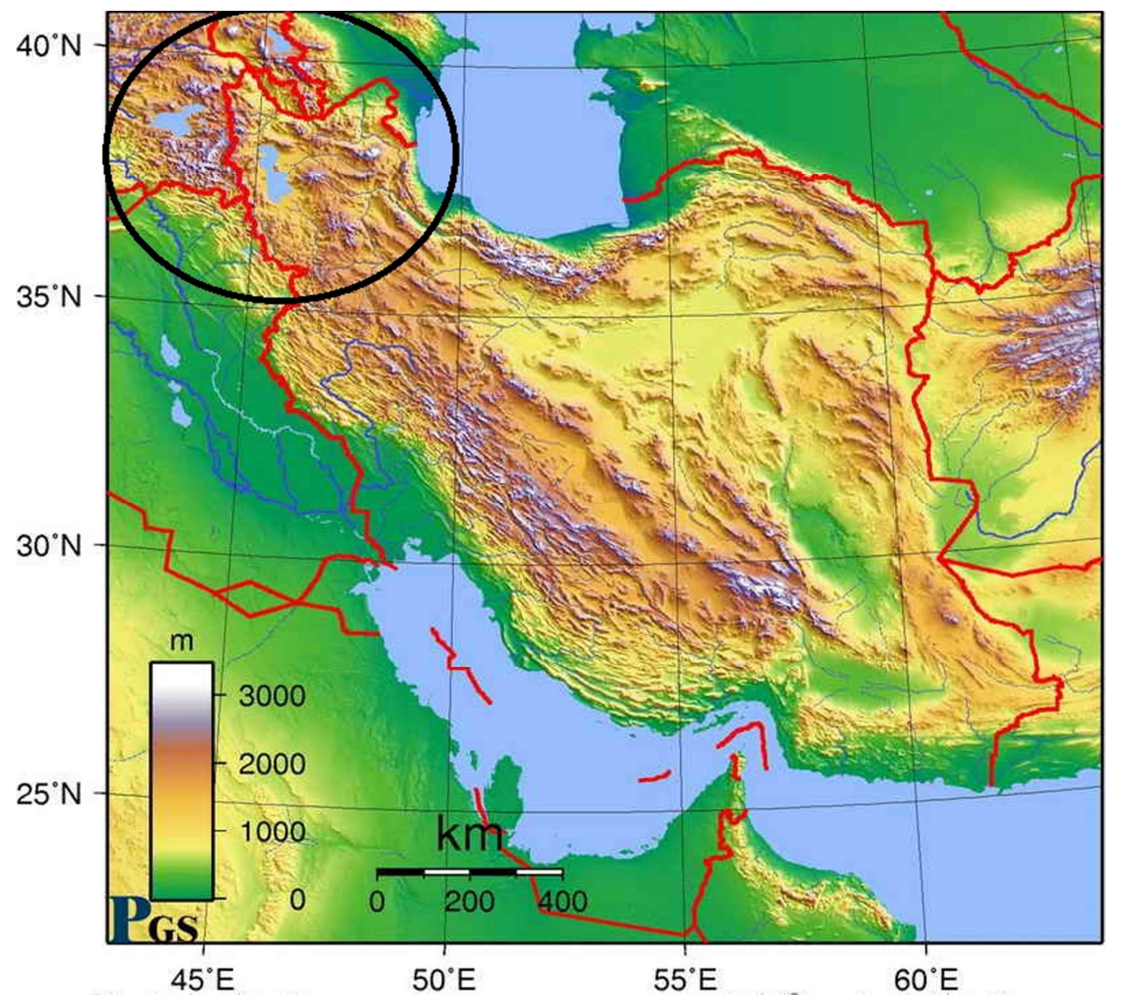

Fig. 1. Azerbaijan Region and Eastern Anatolia.

\subsection{Tepe Hasanlu}

What it can be used for starting this issue, is an event that has occurred at the early of first millennium BC on Hasanlu in Sulduz Valley. Hasanlu IV period is given up in a regretful accident. The related buildings to this period were destroyed due to sudden fire. This fire took placed in such a way that the inhabitants in Hasanlu had no opportunity to leave their buildings. Sudden nature and depth of this catastrophe has caused most of buildings such as burned building II to remain intact with 1500 artifacts and the given objects were left on their original place [20]. Inhabitants in this area had no time to evaluate their properties and most of them have lost their life during extraction of their precious and holy objects from the site. Routine burial in a site is deemed as a contradictory pattern to scenario of invasion as a subject that has not been observed in this site. Many victims have injured on their heads and trace of wound has scarred on their skulls as broken bone (Fig. 2) [20]. More amazing image reveals intention of invaders not for profitability goals and booties but only for massacre. Golden urn and thousands of other spoils remained on the given natural platform is assumed as an evidence for this claim.

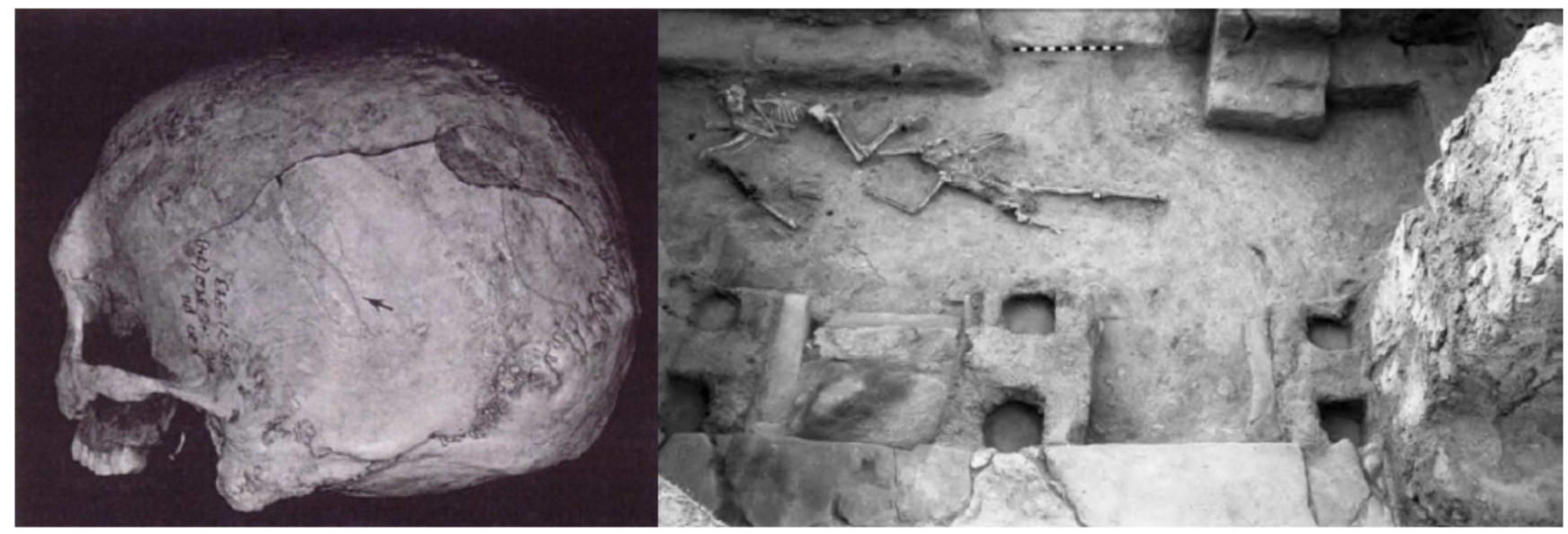




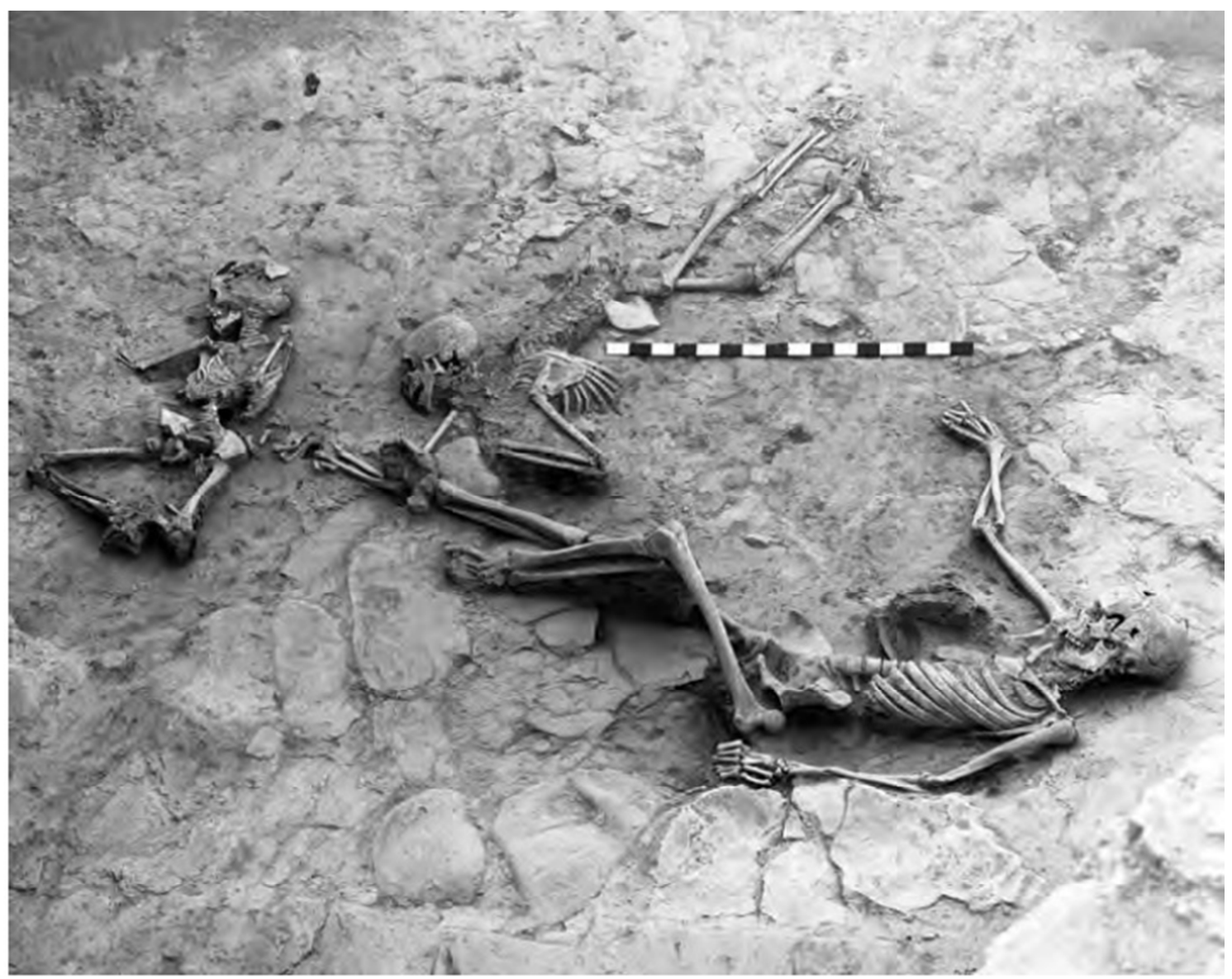

Fig. 2. The left corpses in Room II and building III and picture of skull of an approximately 20-years old young at the south of burned Building XI where he has killed by strike of mace [4].

About 246 skeletons of men and women and children were found in Hasanlu site where they have been either entrapped in fire or subjects to swords and bullets by invaders. The cause of their death is explicitly given blows on their heads or amputation of limbs (hands and feet) [20].

\subsection{Bastam}

There is another area at west Azerbaijan where the given site can be studied in investigations about collapse during Iron Age. This area has been invaded and fired suddenly similar to many sites in Azerbaijan at first millennium BC. What visible on this site is desolation of area due to firing and burned bones [13] \& [21].

\subsection{Agrab Tepe}

It is situated near Dalma village at southwest of Hasanlu site in Sulduz valley. This site has been examined under Hasanlu translation project and excavated for three weeks (Muscarella, 47). In his new works, Muscarella emphasizes in this point that he may be considered as the founders of western archeologists for dealing with time and causes of collapse in areas during Iron Age at Iran. Muscarella claims but is doubtful that destruction and desolation of areas in Iron Age in Iran has occurred simultaneously and within a historical accident and defined event. Muscarella believes that collapse of Agrab Tepe area has taken place synchronously with collapse in Bastam, Haftavan, Zendan II, Ziwiye, Godin II, Tepe Nush-i Jan, and probably Babajan II [20].

\subsection{Dinkha Tepe}

Dinkha Tepe has been excavated during Hasanlu project and also desolated at the end of Iron Age II. Similar to Hasanlu and other great citadels in this region, Dinkha Tepe site was abandoned and seemingly it has not been inhabited until middle of Islamic period [9].

\subsection{Kordlar Tepe}

It is located at the west of Uremia Lake and thirteen kilometers distant from Uremia city. An Austrian archeological panel headed by Andre Lippert has excavated this site between years 1972 and 1974 [15]. During Period IV, some parts of human skeleton were found dispersedly inside Hall- B in which some burning traces were specified on them and according to view of excavator; they could not find a way to exit (Ibid). Simultaneously, at the same time that Hasanlu expedition was excavated in Hasanlu site, Andre Lippert from Austria found burned artifacts in Kordlar Tepe at west Uremia. Burned and left skeletons in this site confirm that they had no way to exit from hall 
while the identical pictures are visible in most of areas of Iron Age at this region. Ziwiye is one of very precious sites in Iran too, where the findings in this area have special position in archeology of Iran at Iron Age, particularly the related treasures found in 1947. Story of sudden destruction and desolation of areas in this period of Iranian history is also visible here. Ziwiye was also destroyed and abandoned in 7 century BC [10].

\section{Analysis of Findings: Reasons for Collapse in Iron Age Settlements}

Presence or absence of Assyrian and Urartian troops in Hasanlu fire is one of the most complicated archeological subjects in Northwest of Iran a subject over which no unanimity has been so far achieved. Dyson and Muscarella, who were excavation supervisors in Hasanlu site and dealt with excavation in this area for several years, attributed persistently all responsibility for destruction to Urartian troops in fourth period. Here, with respect to data from archeologists, we mainly analyze desolation of Urartian areas.

Archeologists even refer to Urartian texts and some of military tactics of Urartian troops e.g. captivation of enemies and they conclude that if this statement is proper, destruction and massacres in Hasanlu IV area may reveal horrendous facts about the prevalent norms in sending off Urartian troops [20]. However, it is surprising that excavations done in Urartian sites e.g. Karmir-Blur, Altıntepe, and Ayanis show these cities were also subjects to fire and cruel massacre at this time [21]. At the same time, Altıntepe, Norshun-Tepe, Kef kalesi, and other Eastern sites of Turkey were also destroyed [20]. Therefore, one should look for other invaders in this region where they have simultaneously invaded western and Northwestern sites of Iran and East Turkey. Also, Urartian regions at East Turkey that located at neighborhood of Northwestern areas of Iran and placed within the same cultural region without drawing political borderlines were subject to destruction and fire and desolated at the end of Iron Age. Most of these areas, which have suffered from crisis synchronously with destructions in Northwestern areas of Iran, showed wide invasions that have targeted Urartu as well. Probably it can be imagined that Urartu has been also victimized although it has been mentioned as factor of destruction in Hasanlu site.

Karmir-Blur is one of Urartian regions that have been destroyed synchronously with Hasanlu IV and despite of this fact that discussion is still in force about accurate date of destruction of Karmir- Blur site among archeologists, this event has probably occurred about year 600BC. However, one can put them in the same time group by comparing given artifacts from Hasanlu IV and Karmir- Blur sites. Ivory and architectural data and potteries and desolation of both sites by war and fire are considered as time and cultural similarities in these two areas [21]. Kayali Dere, NorshunTepe, and Kef Kalesi are also some other sites that have been destroyed in this time (Muscarella, 2009: 153). Therefore, this issue can be accepted as a historic fact that the given Urartian sites have been really destroyed at time periods near to each other namely during end years of $7^{\text {th }}$ century BC (Ibid: 154). This is a subject that should be added to list of Hasanlu IV, Haftavan Tepe, and other areas.

Altıntepe is situated at $20 \mathrm{~km}$ distant from East of Erzincan and beside Erzurum- Soma Road and in a fertile plain. This city was assumed as a very important artistic and military center between cities at Eastern part of Anatolia during 7 and $8^{\text {th }}$ centuries $\mathrm{BC}$ but the above site was desolated by the inhabitants because they felt sense of fear about risk threatened them in years $600-585 \mathrm{BC}$ and it has no longer been populated since that time [12].

Korucutepe in Elazi $\breve{g}$ at East Turkey was destroyed and evacuated similar to Hasanlu after $800 \mathrm{BC}$ up to Seljuk period [2]. Fire took place in Tille Höyük in Adiyaman at Southeast of Turkey in 607BC (Nesbitt, 1988: 86). Also fire has occurred in Arsalantepe with wide and prevailing dimensions at Malatya plain [24]. Karagündüz is one of other Urartian sites in which the monuments have been destroyed by invasion [14]. Ayanis is located at $35 \mathrm{~km}$ distant from North of Van city where Professor Altan Çilingeroğlu has excavated this site in two parts of castle and external area of city in 1991 and the condition of this area has remained unknown from Iron Age II through $11^{\text {th }}$ AD century [25].

It should not be forgotten that role of Assyrian government is apparent in analysis of events at early days and middle of first millennium BC particularly dispatching troops by Sargon II [17]. Even some of archeologists such as Medvedeskaya [18] and Peter Magee [16] have expressed opposite comments about destruction of Hasanlu area but these massacres have occurred without looting wealth of survivors and thereby they exclude Assyrians of group of agents for this collapse as well.

Table 1. List of Collapsed settlement in Azerbaijan.

\begin{tabular}{|c|c|c|c|c|}
\hline Site & Cause of abandonment and collapse & Situation & Excavator & Reference \\
\hline Hasanlu & Destruction, Fire, Abandoned & Sulduz Valley & Dyson & $\begin{array}{l}\text { H. Dyson, Jr., Robert, 1960, "The Death of a City", } \\
\text { Expedition }\end{array}$ \\
\hline Bastam & Destruction, Fire, Abandoned & Qara Zia Eddin & Wolfram Kleiss & $\begin{array}{l}\text { Kleiss, Wolfram, 1969, Ausgrabungen in der } \\
\text { Urartaischen fesyung Bastam (rusahinili), AMI }\end{array}$ \\
\hline Agrab Tape & Destruction, Fire, Abandoned & Sulduz Valley & Dyson & $\begin{array}{l}\text { Muscarella, O. W., "Excavations at Agrab Tepe," } \\
\text { Metropolitan Museum Journal 8, 1973, pp. 47-76. }\end{array}$ \\
\hline Dinkha Tepe & Destruction, Abandoned & Ushno Valley & Dyson & $\begin{array}{l}\text { Muscarella, Oscar White, 1968, Excavation at Dinkha } \\
\text { Tepe 1966, The Metropolitan Museum of Art bulletin, } \\
\text { New series, vol. 27, no 3, pp 187-196. }\end{array}$ \\
\hline
\end{tabular}




\begin{tabular}{|c|c|c|c|c|}
\hline Site & Cause of abandonment and collapse & Situation & Excavator & Reference \\
\hline Kordlar Tepe & Destruction, Fire, Abandoned & Urmia & Lippert, A & $\begin{array}{l}\text { Lippert, A, 1979, Die osterreichischen ausgrabungen } \\
\text { am Kordlar-Tepe in persisch-westaserbeidschan } \\
\text { (1971-1978), AMI, band 12, pp 103-137. }\end{array}$ \\
\hline Ziwiye & Destruction, Abandoned & Saqqiz & Dyson & $\begin{array}{l}\text { Muscarella, O. W., "Excavations at Agrab Tepe," } \\
\text { Metropolitan Museum Journal 8, 1973, pp. 47-76. }\end{array}$ \\
\hline Ayanis & Catastrophic Fire & Van & Altan Çilingiroğlu & $\begin{array}{l}\text { Çilingiroğlu A (1991-2006). Van - Ayanis (Ağartı) } \\
\text { Kalesi kazıları. In: 12. Kazı Sonuçları Toplantısı, } 1 . \\
\text { cilt, pp. } 201 \text { - 207. Ankara: Kültür Bakanlığı Anıtlar } \\
\text { ve Müzeler Genel Müdürlüğü (in Turkish and } \\
\text { English). }\end{array}$ \\
\hline Yoncatepe & $\begin{array}{l}\text { Catastrophic Fire Collapsed and } \\
\text { Damaged }\end{array}$ & Van & $\begin{array}{l}\text { Oktay Belli and } \\
\text { Erkan Konyar }\end{array}$ & $\begin{array}{l}\text { Belli, 2006. Yoncatepe sarayı ve nekropolü. Anadolu } \\
\text { Medeniyetleri Müzesi } 2005 \text { Yillıg1, 20: 381-431. }\end{array}$ \\
\hline Altıntepe & Destructive fire & Erzincan & Tahsin Özgüç & $\begin{array}{l}\text { ÖZGÜÇ, T. 1961-1969 “Altıntepe kazıları,” Belleten } \\
\text { XXV, Vol 97-100: 253-268. }\end{array}$ \\
\hline
\end{tabular}

\section{Conclusion}

One can imply that the reasons and time of collapse of areas are some of foremost unresolved problems in archeology particularly at Northwest Iran and Eastern Anatolia and generally in Iron Age. Artistic and industrial achievements of Iron Age at Northwest are assumed as the latest efforts by people to express their own in historical scene at that time. Serious burning of monuments throughout Azerbaijan followed by hundreds of ancient settlements such as Kultepe and Yanik Tepe are deemed as some evidences for burning and collapse of establishments. After fire and collapse in many areas until Islamic period, even hand-made potteries have not appeared. What it was, collapse swallowed these areas and divest change of living again from craftsmen and creative people in Iron Age. Despite of the given castle and citadel and progress in all artistic, industrial, architectural, military, and cultural fields, Hasanlu area was suddenly destroyed and after collapse of this city, other cities and areas came to the end of life one after another as well. As we witness in Northwest area they approach to the period of destruction after reaching to climax and time of flourishing in some sites e.g. Hasanlu and Bastam. Picture of collapse and destruction of sites and civilizations that explicitly occurred during a period of history totally at Northwest of Iran is an obvious issue with wide geographic dimensions where their roots and causes may be attributed to military and political events and invasion of tribes in first millennium BC. Among them what it assumed as cause of surprise is sudden extinction of industry and art. Accordingly, it can be mentioned that sudden war, pillage, and invasion by invader tribes are the main factor in termination of brilliant Iron Age and art and civilization at this period in history of ancient Iran. Some of these areas that have been defeated in these attacks and their civilizations with thousand years background have been buried under mass of debris and ash so that to be exhumed several thousand years later and they can be evidence for this claim are as follows: Hasanlu, Kordlar Tepe, Agrab Tepe, Dinkha Tepe, and Bastam and most of Urartian sites. One can even add site of Shahar Yeri, Ziwiye, Godin, Babajan Tepe and son to this list
(Table 1) of collapses as well at the end of Iron Age. Whatever the cause of these fires is, it may reveal reason for desolation of this area at this period. Bronze-craftsmen, potters, and architects were entirely burned and or destroyed by hitting blow and production of grey pottery is suddenly disrupted as the foremost characteristics in Iron Age and none of survivors looks for the buried treasures within demolition areas. Anyone of city dwellers is no longer buried in city grave along with iron and bronze embellishments of their own and wind and rain will erode demolished areas and lead to accumulation of tailings, debris, and collection of them throughout the site.

\section{References}

[1] Akhavan Kazemi, Bahram, 1995, The Social Philosophy of Ibn Khaldun, in Gaston Bouthoul View, Din Va Ertebatat (Religion and Communications) Journal, N1, PP 171-209, (In Persian).

[2] Bosseneck, Joachim, von den Driesch, Angele, 1974, The Excavations at Korucutepe, Turkey, 1968-1970: Preliminary Report. Part IX: The Animal Remains, Journal of Near Eastern Studies, Vol. 33, No. 1, pp 109-112.

[3] Carol G. Thomas and Craig Conant, 1999, Citadel to CityState: The Transformation of Greece, 1200-700 B. C. E.

[4] Danti, Michel, Hasanlu V: The Late Bronze and Iron I Periods, Archaeological Survey and Reconnaissance of UšnuSolduz, with contributions by Megan Cifarelli, University of Pennsylvania Museum of Archaeology and Anthropology by the University of Pennsylvania Press.

[5] Diamond, Jared M., 2005. Collapse: How Societies Choose to Fail or Succeed. New York: Viking.

[6] Drews, 1977, Quotes Fernand Braudel's Assessment That the Eastern Mediterranean Cultures Returned Almost To a Starting-Point ("Plan Zéro"), "L'aube", In Braudel, F. (Ed) (1977), La Mediterranee: L'espace ET L'histoire (Paris).

[7] Drews, Robert. 1993, The End of the Bronze Age: Changes in Warfare and the Catastrophe ca. 1200 B. C. Princeton, NJ: Princeton University Press.

[8] Dyson, R and Muscarella, 1989, O. W, Constructing the Chronology and Historical Implications of Hassanlu IV, Iran, V. XXVII. P. P 1-28. 
[9] Dyson, H. Robert, 2010 a, The Death of City, Researches about Hasanlu ancient city, Translated by Samad Elliyun and Ali Sadraei, Ganjine Honar and Miras pub, Volume II, Tehran and Urmia.

[10] Dyson, H. Robert, 2010 b, The People of West Iran in 9 BC., Researches about Hasanlu ancient city, Translated by Samad Elliyun and Ali Sadraei, Ganjine Honar and Miras pub, Volume I, Tehran and Urmia.

[11] Frangipane, Marcella, 2009, Rise and Collapse of the late Uruk centres in upper Mesopotamia and Eastern Anatolia, Scienze dell'antichità storia archeologia antropologia 15 , Università degli studi di Roma «La Sapienza», Rome.

[12] Karaosmanoğlu, Mehmet and Korucu, Halim, 2012, The Apadana of Altintepe in the light of the second season excavations In: Anatolian Iron Ages 7, edited by Altan Çilingiroğlu and Antonio Sagona, Leuven, Paris, Walpole, p. 131-147.

[13] Kleiss, Wolfram, 1969, Ausgrabungen in der Urartaischen fesyung Bastam (rusahinili), AMI.

[14] Köroğlu, Kemallettin and Konyar, Erkan, 2008, "Comments on the Early/Middle Iron Age Chronology of Lake Van Basin", A Re-Assessment of Iron Ages Chronology in Anatolia and Neighboring Regions. Proceedings of a Symposium held at Ege University, İzmir, Turkey, 25-27 May 2005. Ancient Near Eastern Studies, V. 45, p. 123-146.

[15] Lippert, A, 1979, Die Osterreichischen ausgrabungen am Kordlar-tepe in persisch-westaserbeidschan (1971-1978), AMI, band 12, pp 103-137.

[16] Magee, peter, 2008, Deconstructing the destruction of Hasanlu: Archaeology, Imperialism and the chronology of the Iranian Iron Age, Iranica Antiqua, Vol. XLIII, PP 89-106.

[17] Mayer, Walter, 1983, Sargons Fledzug Gegen Urartu-714 v. Chr. Text und Übersetzung, Mitteilungen der Deutschen Orient-Gesellschaft 115, 65-132.

[18] Medvedeskaya, I., 1988, Who destroyed Hasanlu IV?, Iran 26: $1-15$.

[19] Morgan, Lewis Henry, 1877, Ancient Society, Harvard University.
[20] Muscarella, O white, 2007, Hasanlu fight in the late ninth century BC., Hasanlu fortress, Edited by Robert Dyson \& Mary M. Voigt, Translated by Samad Elliyun and Ali Sadraei, Ganjine Honar and Miras pub, Tehran and Urmia.

[21] Muscarella, Oscar white, 2013, Archaeology, Artifacts and Antiquities of the ancient Near East, sites, cultures and proveniences, Chapter Five, Excavation at Agrab Tepe, Iran, BRIL, Boston.

[22] Rahbani, Morteza, 1998, Toynbee and History of civilization, Jahane Ketab, Third year, N. 19\&20, PP 18-19, (In Persian).

[23] Renfrew, Colin, Bahn, Paul, 2005, Archaeology; The Key Concepts, Routledge, London.

[24] Sadori, L., Susanna, F., Balossi Restelli, F., 2004, Collapsed beams and wooden remains from a $3200 \mathrm{BC}$ temple and palace at Arslantepe (Malatya, Turkey), Charcoals from the Past: Cultural and Palaeo environmental Implications Proceedings of the Third International Meeting of Anthracology, Cavallino - Lecce (Italy), June 28th - July $1^{\text {st }}$.

[25] Solmaz, Tuğba, Oybak Dönmez, Emel, 2013, Archaeobotanical studies at the Urartian site of Ayanis in Van province, Eastern Turkey, Turkish Journal of Botany, 37, pp 282-296.

[26] Tainter, Joseph A., 1988, The Collapse of Complex Societies, Cambridge University Press, New York.

[27] Toynbee, Arnold J., 1934-1961, Oxford University, London.

[28] Tsonis, A. A., K. L. Swanson, G. Sugihara, And P. A. Tsonis, 2010, Climate Change And The Demise Of Minoan Civilization, Climate Of The Past, 6, 525-530.

[29] Weiss, Harvey, 1982, "The Decline of Late Bronze Age Civilization as a Possible Response to Climatic Change". Climatic Change 4 (2): 173-198.

[30] Weiss, H., Courty, M. A., Wetterstorm W., Guichard, L., Senior, L., Medow, R. and Curnow, A. 1993. The Genesis and the Collapse of Third Millennium North Mesopotamian Civilization. Science 261: 995-1004.

[31] Young, T. Cyler, 1965, a Comparatives Ceramic Chronology for Western Iran, Iran, No. III, P. P 53-58. 